\title{
Evaluation of Peroxyacetic Acid (PAA) \\ for Controlling Bacterial Soft Rot of some Vegetable Fruits and Potato Tubers Caused by Erwinia carotovora subsp. carotovora
}

Anwar, A. Galal

Plant Pathology Dept., Fac. of Agriculture, Minia Univ, Egypt.

\begin{abstract}
strong oxidizing compound, peroxyacetic acid (PAA) which $A$ formed by mixing hydrogen peroxide $\left(\mathrm{H}_{2} \mathrm{O}_{2}\right)$ with acetic acid, gave a promising control approach against soft rot bacteria. Since, wetting fleshy plant organs by PAA significantly reduced soft rot severity as compared to check organs (untreated organs). All tested vegetable fruits, i.e. eggplant, pepper, tomato, cucumber, squash and okra plus potato tubers were responded to PAA treatment. However, pepper fruits showed the highest protection followed by eggplant, squash, cucumber and okra, while tomato fruits showed the least protection value. Potato tubers gave 50\% protection. Storage temperature is important, since at $35^{\circ} \mathrm{C}$ decay was developed at short period while at $5^{\circ} \mathrm{C}$ was delayed. Efficacy of peroxyacetic acid to reduce bacterial soft rot was differed significantly with both storage temperatures and the tested vegetable fruits or tubers. Either wounded or sound treated vegetable fruits or tubers responded to PAA treatment that showed significant reduction in soft rot severity by $41.1-72.2 \%$ in case of unwounded treated vegetable fruits or tubers by about $20-66 \%$ in case of wounded treated vegetable fruits or tubers. PAA was more effective to reduce bacterial soft rot severity when unwounded fruits or tubers were pre-inoculation treated.
\end{abstract}

Keywords: Acetic acid, Erwinia carotovora subsp. carotovora Hyrdrogen peroxide and Peroxyacetic Acid.

Sanitation after harvest is critically important for all fresh products, where it can reduce spoilage losses by $50 \%$ or more (Sargent et al., 2000). This occurs primarily by the sanitation of wash water, produce surfaces, equipment, and storage rooms rather than direct control of infections of the decay pathogens within the produce. The most common disinfecting agent is chlorine applied as a spray or dip. Sanitation may be followed by treatment with one or more fungicides, which deposit a residue in the product that inhibits decay pathogens which infect later or escapes the action of the sanitizers. Sanitizers are also widely employed to minimize contamination of product with pathogens of human health concern (Gómez-López, 2012). Postharvest decay caused by soft rot bacterium, Erwinia carotovora subsp. carotovora damages succulent plant parts such as fruits, tubers, stems and bulbs of plants in almost plant families (Ouf et al., 1991, Youssef et al., 2006). Soft rot is one of the destructive diseases of vegetables and occurs worldwide wherever fleshy storage tissues of vegetables and ornamentals are found. It causes a greater total loss of 
product than any other bacterial disease. The disease can be found on crops in the field, in transit, in storage and during marketing, resulting in great economic losses.

Name of the disease are used from the characteristic soft decay of fleshy tissue which terminates into watery or slimy mass. The decay is aggravated when high humidity is coupled with high temperature which results in fast rate of multiplication of the pathogen. For this reason much of the loss due to this disease occurs during middle of the summer. Control of the disease includes sanitation of packing house, lowering of storage temperature and humidity (Bhat et al., 2010 and Opara and Austin, 2016).

Oxidative burst, mediated by hydrogen peroxide $\left(\mathrm{H}_{2} \mathrm{O}_{2}\right)$, has been recognized as a key component of plant defense response during an incompatible interaction. Elevated levels of $\mathrm{H}_{2} \mathrm{O}_{2}$ also activated the expression of several defense genes to both bacterial and fungal pathogens (Kachroo et al., 2003). $\mathrm{H}_{2} \mathrm{O}_{2}$ participates in many resistance mechanisms, including reinforcement of the plant cell wall, phytoalexin production, and enhancement of resistance to various stresses (Shetty et al., 2007 and Quan et al., 2008). Acetic acid exhibited fungicidal and bactericidal effect towards several phytopathogenic fungi and bacteria (Kang et al., 2003 and Osório et al., 2013). Hydrogen peroxide $\left(\mathrm{H}_{2} \mathrm{O}_{2}\right)$, also termed as hydrogen dioxide, has antimicrobial properties due to its strong oxidizing power and its capacity to generate other oxidizing species such as hydroxyl radicals, singlet oxygen species, and hydrogen peroxides, which are toxic to living cells. Inactivation of membrane respiratory chain enzymes and damage to DNA are the mechanisms of antimicrobial action proposed for hydrogen peroxide (Imlay and Linn, 1988; Tatsuzawa et al., 1998).

The application of $\mathrm{H}_{2} \mathrm{O}_{2}$ produces no residues since it decomposes to water and oxygen (Afek et al., 1999). $\mathrm{H}_{2} \mathrm{O}_{2}$ is a strong oxidizer that forms when water combines with ozone in the atmosphere (Slesak et al., 2007). In an activated peroxyacetic acid disinfectant $\mathrm{H}_{2} \mathrm{O}_{2}$ is combined with an organic acid (most commonly acetic acid) which acts as an "activator" to form the compound peroxyacetic acid (Fig. 1), so that these disinfectants consist of $\mathrm{H}_{2} \mathrm{O}_{2}$ and peroxyacetic acid in solution.

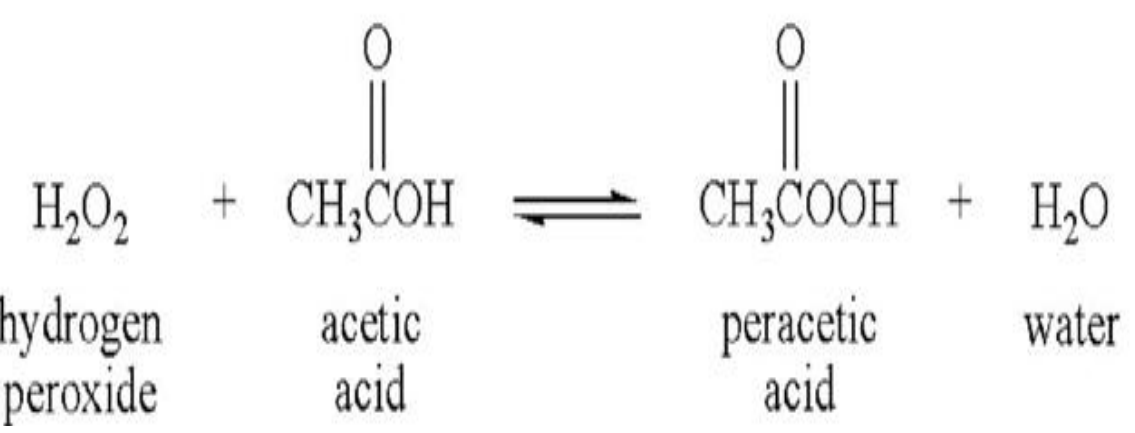

Fig. 1. Production of peracetic acid (Buschmann and Del Negro 2012). 
The present study was planned to evaluate the efficiency of PAA for controlling post-harvest bacterial soft rot to fleshy organs of some vegetables that quickly spoilaged by bacteria.

\section{Materials and Methods}

\section{Casual Agents:}

The most aggressive Erwinia carotovora subsp. carotovora isolate which isolated from soft rotted tissue of potato tubers (Youssef et al., 2006) was used throughout this study.

\section{Preparation of tested solutions:}

Three mixtures of acetic acid (AA) and hydrogen peroxide $\left(\mathrm{H}_{2} \mathrm{O}_{2}\right)$, i.e., $0.05 \mathrm{~g} / \mathrm{l}$ acetic acid $+0.1 \mathrm{H}_{2} \mathrm{O}_{2} \mathrm{~g} / \mathrm{l}, 0.1$ acetic acid $+1.0 \mathrm{H}_{2} \mathrm{O}_{2} \mathrm{~g} / \mathrm{l}$ and $0.2 \mathrm{~g} / \mathrm{l}$ acetic acid + $1.0 \mathrm{H}_{2} \mathrm{O}_{2} \mathrm{~g} / \mathrm{l}$ were prepared with distilled water then left for at least 10 days before they tested (EPA, 1993 and 2004).

3. In vitro control of soft rot bacteria with hydrogen peroxide and acetic acid combinations:

The toxicity of hydrogen peroxide and/or acetic acid with different concentrations on growth of Erwinia carotovora subsp. carotovora isolate in nutrient broth medium (NBM) was studied.

Equal $0.5 \mathrm{ml}$ of bacterial suspension $10^{8}$ colony forming cells $(\mathrm{cfc} / \mathrm{ml})$ were taken from $24 \mathrm{~h}$ old cultures grown on nutrient agar medium (NA) at $28^{\circ} \mathrm{C}$ and used for inoculation of $250 \mathrm{ml}$ Erlenmeyer flasks containing $99.5 \mathrm{ml}$ sterilized nutrient broth medium amended with tested solutions (Ouf et al., 1991). Solutions were prepared in sterile distilled water and aliquots were pipetted to nutrient broth medium to obtain final concentration of tested solution $0.05,0.1$, and $0.2 \mathrm{~g} / \mathrm{l}$ acetic acid, $1.0 \mathrm{~g} / 1 \mathrm{H}_{2} \mathrm{O}_{2}, 0.05 \mathrm{~g} / \mathrm{l}$ acetic acid $+1.0 \mathrm{~g} / \mathrm{H} \mathrm{H}_{2} \mathrm{O}_{2}, 0.1 \mathrm{~g} / \mathrm{l}$ acetic acid $+1.0 \mathrm{~g} / \mathrm{l}$ $\mathrm{H}_{2} \mathrm{O}_{2}$ and $0.2 \mathrm{~g} / \mathrm{l}$ acetic acid $+1.0 \mathrm{~g} / \mathrm{l} \mathrm{H}_{2} \mathrm{O}_{2}$. For control treatment conical flasks containing medium without tested chemicals were inoculated similarly to be taken for comparison. Each treatment was incubated at $28^{\circ} \mathrm{C}$ for 2 days. Bacterial growth was monitored as number of bacterial cells, 3 plates/treatment, using serial dilution technique (Galal, 2003). The following equation was used to calculate percentage inhibition of bacterial growth.

Inhibition $\%=(\mathrm{NB}$ of the control $-\mathrm{NB}$ of the treatment/NB of control) X100 Where NB $=$ Average number of bacterial colonies/plate

4. Efficacy of acetic acid combined with $\mathrm{H}_{2} \mathrm{O}_{2}$ to control soft rot disease of some vegetable fruits and potato tubers in storage:

The fungicide Monceren (Pencycuron) 25\% WP was used as seed dressing fungicide at rate $3 \mathrm{~g} / \mathrm{kg}$ seeds.

\subsection{Pre-inoculation treatment:}

Based on the results of the in vitro test, only the mixture of $0.02 \mathrm{~g} / \mathrm{l} \mathrm{AA}+0.1$ $\mathrm{g} / 1 \mathrm{H}_{2} \mathrm{O}_{2}$ was used to control soft rot disease of cucumber (Cucurnis sativus, cv. Marwa), pepper (Capsicum annum cv. Romy), tomato (Solanum lycopersicum cv. Super Jackal), eggplant (Solanum melongena cv. Balady Black), squash (Cucurbita 
pepo cv. Eskandrany) and okra (Hibiscus esculentus cv. Balady) fruits plus potato (Solanium tuberosium cv. Cara) tubers were purchased from wholesale market. Health apparent uniformed size samples of each fruits or tubers were dipped in 0.02 $\mathrm{g} / \mathrm{AA}+0.1 \mathrm{~g} / 1 \mathrm{H}_{2} \mathrm{O}_{2}$ solution individually for $30 \mathrm{~min}$ prior to inoculation with soft rot bacteria E. carotovora subsp. carotovora. After dipping, samples were air dried at room temperature and each sample of each plant organs tested were divided into 2 major groups, $1^{\text {st }}$ group was wounded (punctured with sharp needle) and $2^{\text {nd }}$ group was left sound similarly as described by (Youssef et al., 2006). Either wounded or sound samples were divided into 2 parts, one inoculated and other left un-inoculated. Treated and untreated fruits or tubers were inoculated by spraying of bacterial inoculum. Bacterial inoculum was prepared from fresh cultures of soft rot bacteria grown on NA at $28^{\circ} \mathrm{C}$ for $24 \mathrm{hr}$ suspended in sterilized distilled water at $10^{9} \mathrm{cfu}$. Untreated control was maintained for each fruits, which was inoculated with the bacterial inoculum but not treated with test solution. The disease severity was measured in terms of percentage of rotted weight infected of the fruits or tubers by soft rot (Youssef et al., 2006), when the untreated inoculated fruits/tubers gave $100 \%$ of soft rot incidence, time required (days) for soft rot development was recorded.

\subsection{Post-inoculation treatment:}

Inoculated and un-inoculated samples were left one hour then were wetted by PAA at concentrations of 0.0 (control), and $0.02 \mathrm{~g} / \mathrm{l} \mathrm{AA}+0.1 \mathrm{~g} / 1 \mathrm{H}_{2} \mathrm{O}_{2}$. Each sample contains 10 vegetable fruits or potato tubers, sprayed by $10 \mathrm{ml}$ test solution in plastic bag then bags were closed tightly for $30 \mathrm{~min}$. After that, plastic bags were opened and samples were dried and retagged into new plastic bags.

Each treatment was divided into 2 groups, one kept at high temperature $35^{\circ} \mathrm{C}$ and the other kept at $5^{\circ} \mathrm{C}$. Each treatment contained 3 replicates. Disease assessment was monitored when samples of inoculated water treated showed $100 \%$ soft rot incidence at each incubation temperature individually. The severity was measured in terms of percentage of rotted weight infected of the fruits by soft rot disease (Youssef et al., 2006), when the untreated inoculated fruits /tubers gave $100 \%$ of soft rot incidence, time required (days) for soft rot development was recorded. Reduction percentage in soft rot severity was calculated using the following equation:

$$
\text { Reduction } \%=(\text { DSUI }- \text { DSTI/DSUI }) \text { X100 }
$$

Where, DSUI $=$ Disease severity of untreated inoculated samples and DSTI= Disease severity of treated inoculated samples

5. Statistical analysis:

Tukey test for multiple comparisons among means was utilized (Neler et al., 1985). 


\section{R e s u l t s}

1. The toxicity of hydrogen peroxide and/or acetic acid combinations to soft rot bacteria in vitro:

An obvious antibacterial activity against soft rot bacteria E. carotovora subsp. carotovora was exhibited by different combinations of AA and/or $\mathrm{H}_{2} \mathrm{O}_{2}$ tested (Table 1). Growth of bacteria completely inhibited in case of combination $0.2 \mathrm{~g} / \mathrm{l} \mathrm{AA}$ $+1.0 \mathrm{~g} / \mathrm{l} \mathrm{H}_{2} \mathrm{O}_{2}$, while at lowest concentration of combine $\left(0.05 \mathrm{~g} / \mathrm{l} \mathrm{AA}+1.0 \mathrm{~g} / \mathrm{l} \mathrm{H}_{2} \mathrm{O}_{2}\right)$ was failed to inhibit the growth of test bacteria. At moderate concentration of combine $\left(0.1 \mathrm{~g} / \mathrm{l} \mathrm{AA}+1.0 \mathrm{~g} / \mathrm{l} \mathrm{H}_{2} \mathrm{O}_{2}\right)$ inhibits $80 \%$ of $E$. carotovora subsp. carotovora growth. Laboratory evaluation has given promising results, indicating that combining $\mathrm{AA}+\mathrm{H}_{2} \mathrm{O}_{2}$ may has potential in the control of soft rot bacterial disease of some vegetable fruits or potato tubers.

Table 1. Antibacterial activity of acetic acid + hydrogen peroxide combinations against $E$. carotovora subsp. carotovora in vitro)

\begin{tabular}{|l|c|c|}
\hline Treatment and conc. $(\mathbf{g} / \mathbf{l})$ & $\begin{array}{c}\text { No. of } \\
\text { bacterial } \\
\text { colonies/plate }\end{array}$ & Inhibition \% \\
\hline $0(\mathrm{Control})$ & 178 & 0.0 \\
\hline $\mathrm{H}_{2} \mathrm{O}_{2}(1.0)$ & 96 & 46.0 \\
\hline AA $(0.05)$ & 160 & 10.1 \\
\hline AA $(0.1)$ & 130 & 27.0 \\
\hline AA $(0.2)$ & 105 & 41.0 \\
\hline AA $+\mathrm{H}_{2} \mathrm{O}_{2}(0.05+1.0)$ & 124 & 30.3 \\
\hline AA $+\mathrm{H}_{2} \mathrm{O}_{2}(0.1+1.0)$ & 36 & 79.8 \\
\hline AA $+\mathrm{H}_{2} \mathrm{O}_{2}(0.2+1.0)$ & 0.0 & 100 \\
\hline
\end{tabular}

2. Efficacy of acetic acid combined with hydrogen peroxide to control bacterial soft rot disease of some vegetable fruits or potato tubers in storage:

\subsection{Pre-inoculation treatment:}

Generally, pre-inoculation treatment of vegetable fruits or potato tubers with $0.2 \mathrm{~g} / \mathrm{l} \mathrm{AA}+1.0 \mathrm{~g} / \mathrm{H} \mathrm{H}_{2} \mathrm{O}_{2}$ combination caused significant reduction in bacterial soft rot under all conditions tested (Table 2). Untreated wounded fruits or tubers gave soft rot severity higher than untreated unwounded plant parts inoculated. Since untreated wounded inoculate- fruits of okra, pepper, and tomato showed $100 \%$ soft rot severity at $35^{\circ} \mathrm{C}$ temperature followed by cucumber (96\%), eggplant (94\%) and potato tubers $(88 \%)$, while unwounded untreated inoculated fruits of okra exhibited highest soft rot severity (95\%) followed by squash (94\%). Eggplant and tomato $(86 \%)$, pepper $(70 \%)$ and potato $(64 \%)$. Either wounded or unwounded treated fruits or tubers responded to PAA treatment that showed significant reduction in soft rot 
severity by $31.9-76.2 \%$ in case unwounded treated vegetable fruits or potato tubers and by about $20-66.7 \%$ in case wounded treated plant parts. PAA was more effective to reduce soft rot severity when unwounded plant parts were preinoculation treated.

\section{Post-inoculation treatment:}

Data summarized in Table 3 showed that PAA was more effective to reduce bacterial soft rot when it applied post-inoculation, since in case of unwounded treated vegetable fruits or potato tubers provided soft rot.

Table 2. In vivo effect of pre-inoculation treatment by hydrogen peroxide and acetic acid combination on the severity of bacterial soft rot to some vegetable fruits/tubers

\begin{tabular}{|c|c|c|c|c|c|c|c|}
\hline \multirow{3}{*}{$\begin{array}{c}\text { Treatment } \\
\text { (Fruits or } \\
\text { potato } \\
\text { tubers) }\end{array}$} & \multirow{3}{*}{\begin{tabular}{|c|} 
storage \\
temperature \\
$\left({ }^{\circ} \mathrm{C}\right)$
\end{tabular}} & \multicolumn{6}{|c|}{ Bacterial soft rot severity \% } \\
\hline & & \multicolumn{3}{|c|}{ Unwounded } & \multicolumn{3}{|c|}{ Wounded } \\
\hline & & Treated & Untreated & $\begin{array}{c}\text { Reduction } \\
\%\end{array}$ & Treated & Untreated & $\begin{array}{c}\text { Reduction } \\
\%\end{array}$ \\
\hline \multirow[t]{2}{*}{ Cucumber } & 5 & $34^{\mathrm{f}}$ & $64^{\mathrm{cd}}$ & 46.9 & $40 f$ & $82^{c}$ & 51.2 \\
\hline & 35 & $46^{\mathrm{de}}$ & $78^{\mathrm{c}}$ & 41.1 & $60 d$ & $96^{\mathrm{b}}$ & 37.5 \\
\hline \multirow[t]{2}{*}{ Eggplant } & 5 & $10^{\mathrm{h}}$ & $20^{\mathrm{g}}$ & 50.0 & $20 \mathrm{~g}$ & $60^{\mathrm{d}}$ & 66.7 \\
\hline & 35 & $30^{\mathrm{g}}$ & $86^{\mathrm{b}}$ & 65.1 & $52 \mathrm{e}$ & $94^{\mathrm{ab}}$ & 44.7 \\
\hline \multirow[t]{2}{*}{ Okra } & 5 & $20^{\mathrm{g}}$ & $60^{\mathrm{d}}$ & 66.7 & $34 \mathrm{f}$ & $58^{\mathrm{de}}$ & 41.4 \\
\hline & 35 & $40^{\mathrm{e}}$ & $95^{\mathrm{a}}$ & 57.9 & $80 \mathrm{c}$ & $100^{\mathrm{a}}$ & 20.0 \\
\hline \multirow{2}{*}{ Pepper } & 5 & $10^{\mathrm{h}}$ & $40^{\mathrm{e}}$ & 75.0 & $36 f$ & $62^{\mathrm{d}}$ & 41.9 \\
\hline & 35 & $40^{\mathrm{e}}$ & $70^{\mathrm{c}}$ & 42.9 & $50 \mathrm{e}$ & $100^{\mathrm{a}}$ & 50.0 \\
\hline \multirow[t]{2}{*}{ Potato } & 5 & $10^{\mathrm{h}}$ & $42^{\mathrm{e}}$ & 76.2 & $26 \mathrm{~g}$ & $58^{\mathrm{de}}$ & 55.2 \\
\hline & 35 & $34^{\mathrm{ef}}$ & $64^{\text {cd }}$ & 46.9 & $48 \mathrm{f}$ & $88^{\mathrm{b}}$ & 45.5 \\
\hline \multirow[t]{2}{*}{ Tomato } & 5 & $30^{\mathrm{f}}$ & $68^{c}$ & 55.9 & $46 \mathrm{e}$ & $78^{\mathrm{c}}$ & 42.0 \\
\hline & 35 & $50^{\mathrm{d}}$ & $86^{\mathrm{b}}$ & 41.0 & $78 \mathrm{c}$ & $100^{\mathrm{a}}$ & 22.0 \\
\hline \multirow[t]{2}{*}{ Squash } & 5 & $42^{\mathrm{e}}$ & $74^{c}$ & 43.2 & $50 \mathrm{e}$ & $82^{c}$ & 39.0 \\
\hline & 35 & $64^{\mathrm{cd}}$ & $94^{\mathrm{a}}$ & 31.9 & $78 \mathrm{c}$ & $100^{\mathrm{a}}$ & 22.0 \\
\hline
\end{tabular}

Data with the same letters are not significant

Reduction by about 51.3- 82.2\%, while with wounded treated plant parts, soft rot was lower and ranged from 25 to $77.4 \%$. Effect of PAA to reduce soft rot severity varied with the tested fruits or tubers and storage temperature tested. As for unwounded treated fruits or tubers, highest reduction in soft rot severity was recorded by potato tubers $\left(82.2 \%\right.$ followed by okra fruits $(77,8 \%)$, pepper $(76.2)$ at $5^{\circ} \mathrm{C}$. Fruits of cucumber showed least reduction percentage in soft rot severity $(51.4 \%)$ followed by tomato $(54.8 \%)$, pepper $(57.6 \%)$ at $35^{\circ} \mathrm{C}$. Wounded treated fruits or tubers 
resulted lower reduction in bacterial soft rot disease and varied with various fruits or tubers and storage temperature as compared to unwounded treated ones. Wounded untreated vegetable fruits or potato tubers showed bacterial soft rot severity higher than unwounded ones.

Table 3. In vivo effect of post-inoculation treatment by hydrogen peroxide and acetic acid combination on the severity of bacterial soft rot to some vegetable fruits or tubers

\begin{tabular}{|c|c|c|c|c|c|c|c|}
\hline \multirow{3}{*}{$\begin{array}{c}\text { Treatment } \\
\text { (Fruits or } \\
\text { potato tubers) }\end{array}$} & \multirow{3}{*}{$\begin{array}{c}\text { Storage } \\
\text { temperature } \\
\left({ }^{\circ} \mathbf{C}\right)\end{array}$} & \multicolumn{6}{|c|}{ Bacterial soft rot severity \% } \\
\hline & & \multicolumn{3}{|c|}{ Unwounded } & \multicolumn{3}{|c|}{ Wounded } \\
\hline & & Treated & Untreated & $\underset{\%}{\text { Reduction }}$ & Treated & Intreated & $\begin{array}{c}\text { Reduction } \\
\%\end{array}$ \\
\hline \multirow[t]{2}{*}{ Cucumber } & 5 & $18^{\mathrm{f}}$ & $68^{\mathrm{c}}$ & 73.6 & $22^{\mathrm{g}}$ & $78^{\mathrm{d}}$ & 71.8 \\
\hline & 35 & $35^{\mathrm{e}}$ & $72^{c}$ & 51.4 & $44^{\mathrm{f}}$ & $92^{\mathrm{ab}}$ & 52.2 \\
\hline \multirow[t]{2}{*}{ Eggplant } & 5 & $8^{\mathrm{gh}}$ & $24^{\mathrm{f}}$ & 66.7 & $14^{\mathrm{I}}$ & $62^{\mathrm{e}}$ & 77.6 \\
\hline & 35 & $24^{\mathrm{f}}$ & $82^{\mathrm{b}}$ & 76.7 & $36^{\mathrm{f}}$ & $90^{\mathrm{b}}$ & 60.0 \\
\hline \multirow[t]{2}{*}{ Okra } & 5 & $12^{\mathrm{d}}$ & $54^{\mathrm{d}}$ & 77.8 & $28^{\mathrm{gh}}$ & $62^{\mathrm{e}}$ & 54.8 \\
\hline & 35 & $34^{\mathrm{d}}$ & $92^{\mathrm{a}}$ & 63.0 & $62^{\mathrm{e}}$ & $100^{\mathrm{a}}$ & 38.0 \\
\hline \multirow[t]{2}{*}{ Pepper } & 5 & $10^{\mathrm{f}}$ & $42^{\mathrm{d}}$ & 76.2 & $32^{f}$ & $64^{\mathrm{e}}$ & 50.0 \\
\hline & 35 & $28^{\mathrm{e}}$ & $66^{\mathrm{c}}$ & 57.6 & $38^{\mathrm{fg}}$ & $100^{\mathrm{a}}$ & 62.0 \\
\hline \multirow[t]{2}{*}{ Potato } & 5 & $8^{\mathrm{De}}$ & $45^{\mathrm{f}}$ & 82.2 & $22^{\mathrm{g}}$ & $54^{\mathrm{f}}$ & 59.3 \\
\hline & 35 & $26^{\mathrm{e}}$ & $63^{c}$ & 58.7 & $36^{\mathrm{fg}}$ & $86^{\mathrm{b}}$ & 58.1 \\
\hline \multirow[t]{2}{*}{ Tomato } & 5 & $24^{\mathrm{e}}$ & $72^{c}$ & 66.7 & $42^{f}$ & $80^{\mathrm{bc}}$ & 47.5 \\
\hline & 35 & $38^{\mathrm{e}}$ & $84^{b}$ & 54.8 & $68^{\mathrm{de}}$ & $100^{\mathrm{a}}$ & 32.0 \\
\hline \multirow[t]{2}{*}{ Squash } & 5 & $38^{\mathrm{e}}$ & $78^{\mathrm{bc}}$ & 51.3 & $60^{\mathrm{e}}$ & $85^{\mathrm{b}}$ & 29.4 \\
\hline & 35 & $70^{\mathrm{c}}$ & $95^{\mathrm{a}}$ & 26.3 & $75^{\mathrm{d}}$ & $100^{\mathrm{a}}$ & 25.0 \\
\hline
\end{tabular}

Data with the same letters are not significant

3. Bacterial soft rot development in vegetable fruits or potato tubers:

Incubation period (days) that required to exhibit $100 \%$ of bacterial soft rot disease was varied with different vegetable fruits/tubers and storage temperature tested (Table 4). Generally, at $35^{\circ} \mathrm{C}$ soft rot developed at shorter period than at $5^{\circ} \mathrm{C}$ and wounded fruits/tubers accelerated soft rot development faster than unwounded ones. Wounded fruits of squash required shortest period to exhibit $100 \%$ soft rot (3 days) followed by cucumber, okra, pepper and tomato (4 days), potato tubers (5days) and eggplant (6 days) at storage temperature $35^{\circ} \mathrm{C}$. At $5^{\circ} \mathrm{C}$ delayed decay development of wounded inoculated fruits where, tomato required 7days, followed by squash 10 days, cucumber 12, okra 14, eggplant 15 , pepper 16 and potato 35 days. Unwounded inoculated fruits or tubers extended incubation period from 1.5 to 2 fold 
as compared to wounded ones when the fruits or tubers stored at $5^{\circ} \mathrm{C}$, and from 1.5 to 9 fold when they stored at $35^{\circ} \mathrm{C}$.

Table 4. Incubation periods (days) required for $100 \%$ bacterial soft rot incidence in vegetable fruits/tubers at $5^{\circ} \mathrm{C}$ and $35^{\circ} \mathrm{C}$ storage temperature under artificial inoculation by Erwinia carotovora subsp. carotovora

\begin{tabular}{|l|c|c|c|c|c|c|c|c|}
\hline \multirow{2}{*}{ Treatment } & $\begin{array}{c}\text { Storage } \\
\text { temperature } \\
\left({ }^{\mathbf{0}} \mathbf{C}\right)\end{array}$ & \multicolumn{6}{|c|}{ Days of storage required to soft rot incidence for: } \\
\cline { 3 - 9 } & 5 & Cucumber & Eggplant & Okra & Pepper & Potato & Tomato Squash \\
\hline Unwounded & 55 & 8 & 24 & 24 & 27 & 75 & 12 & 21 \\
& 35 & & & 6 & 18 & 45 & 6 & 6 \\
Wounded & 5 & 12 & 15 & 14 & 16 & 35 & 7 & 10 \\
& 35 & 4 & 6 & 4 & 4 & 5 & 4 & 3 \\
\hline
\end{tabular}

\section{D i s c u s s i o n}

The minimal requirement from disinfection procedures is to maintain commodities and facilities free of postharvest pathogens and bacterial human pathogens and thus improve food safety. Disinfection of postharvest pathogens that accumulate on the fruit surface before and during harvest is a direct benefit and in particular cases it can by itself prevent decay after storage (Feliziani et al., 2016). A nonspecific phytopathogenic bacterium Erwinia carotovora subsp. carotovora that infects most fleshy plant parts its control still difficult through various control methods even chemicals which improper for human health and environment (Bartz and Kelman, 1986 and Ouf et al., 1991). Safety elements became must to be beneficial used as bactericide alternatives (Himel et al., 2017). Thus, acetic acid (Himel et al., 2017) and $\mathrm{H}_{2} \mathrm{O}_{2}$ (Kiraly et al., 1993 and EPA, 2012) were used individually or with various combinations to reduce $E$. carotovora subsp. carotovora growth and infectivity.

Like other oxidizing disinfectants, $\mathrm{H}_{2} \mathrm{O}_{2}$ and peroxyacetic acids disinfect by oxidizing the cell membranes and inner cell structures of the pathogens, destroying them. Bio safe compound (peroxyacetic acid) is produced commercially in USA under various trade names BioSafe, OxiDate, and OxiCure) in Japan (Tsunami) and in South korea (OxyCom) as mentioned by several reports (Afek et al., 2001, Narcis et al., 2007, Hopkins et al., 2003, Hopkins et al., 2009, Pfuntner, 2011 and EPA, 2012).

In vitro studies showed $\mathrm{H}_{2} \mathrm{O}_{2}$ was effective to suppress bacterial growth, recorded high inhibitory effect to bacterial growth (up to $60 \%$ inhibition). Acetic acid showed reduction in bacterial growth and increased with increasing its concentration. Combining acetic acid and $\mathrm{H}_{2} \mathrm{O}_{2}$ caused significant reduction towards bacterial growth. Complete inhibition in bacterial growth was achieved by combine $0.2 \mathrm{~g} \mathrm{AA} / \mathrm{l}+1.0 \mathrm{~g} \mathrm{H}_{2} \mathrm{O}_{2} / 1$. 
Application of combined $\mathrm{H}_{2} \mathrm{O}_{2}$ with acetic acid at a concentration $(0.2 \mathrm{AA}+1.0$ $\mathrm{H}_{2} \mathrm{O}_{2}$ ) g/l to vegetable fruits/tubers pre- or post-inoculation caused significant reduction in bacterial soft rot severity. Effectiveness of PAA was varied with fruits and storage temperature. Data indicate that PAA has effective reaction to reduce soft rot severity even at low storage temperature more or less nearly to high temperature. The obtained results assured that PAA is benefit to control bacterial soft rot when it applied pre- or post-inoculation treatment. Beside its disinfectant effect of PAA, it could be used as curable compound against bacterial soft rot. Efficiency of PAA to reduce soft rot severity more pronounced when it post-inoculation applied as compared to pre-inoculation treatment. Moreover, PAA reduced soft rot of unwounded fruits/tubers more than wounded ones.

As early as in 1928, Doran pointed out that acetic acid reacted as antibacterial, similarly as confirmed by Himel et al. (2017). Also, $\mathrm{H}_{2} \mathrm{O}_{2}$ which reacted as active oxygen species provided bactericidal effects towards various phytopathogenic bacteria (Hopkins et al., 2003, Hopkins et al., 2009, EPA, 2004 and Pfuntner, 2011). A disinfectant PAA is promising to work as a bactericide alternatives safe compound not only to bacterial soft rot but against several phytopathogenic fungi and bacteria. However, $\mathrm{H}_{2} \mathrm{O}_{2}$ acetic acid and their mixture are safe, degradable compounds and reacted as fungicides, bactericides and resistance inducers (Kitis, 2004, Thipaksorn et al., 2012 and Wessels and Ingmer, 2013), Furthermore, there compounds are approved to control phytopathogenic fungi and bacteria in organoculture and aquaculture (Yanong and Reid, 2012).

\section{Conclusion}

PAA is effective to reduce soft rot severity and its efficiency was pronounced more when it applied post-inoculation than pre-inoculation at either low or high storage temperatures tested. Due to its promising approach for controlling plant diseases, PAA took more attention in our laboratory since 3 years ago and now under preparation to publish several further studies on postharvest, soil borne and foliar diseases.

\section{A cknow ledge me nt}

Great thanks go to Dr. Abdel-Latif, M. R., Prof. Plant Pathology, Plant Pathol. Dept., Fac. Agric., Minia University, El-Minia, Egypt, for his critical reviewing this manuscript. Also, thanks to Dr. Zaki, H.E., associate Prof., Vegetable Crops, Hort. Dept., Minia Univ. for determining cultivars of vegetable fruits or potato tubers. 


\section{Refere n c e s}

Afek, U.; Orenstein, J. and Nuriel, E., 1999. Fogging disinfectants inside storage rooms against pathogens of potatoes and sweet potatoes. Crop Prot., 18(2): $111-114$.

Afek, U.; Orenstein, J. and Kim, J.J., 2001. Control of silver scurf disease in stored potato by using hydrogen peroxide plus (HPP). Crop Prot., 20:69-71.

Bartz, J. A. and Kelman, A. 1986. Reduction the potential for bacterial soft rot in potato tubers by chemical treatments and drying. American Potato Journal, 63:481-492.

Bhat, K, A.; Masood, S. D.; Bhat, N.A.; Bhat, M. A.; Razvi, S. M.; Mir, M. R; Sabina Akhtar; Wani, N. and Habib, M. 2010. Current status of postharvest soft rot in vegetables: A Review. Asian Journal of Plant Sciences, 9(4):200-208.

Buschmann, W. E. and Del Negro A. S. 2012. Production of peroxycarboxylic acids. USA Patent US8318972B2. 845 November 27.

Doran, W. L. 1928. Acetic acid as a soil disinfectant. Journal of Agriculture Research, 36(3):261-280.

EPA (Environmental Protection Agency). 1993. R.E.D. Facts. Peroxy Compounds. Prevention, Pesticides and Toxic Substances. EPA-738-F-93-026. https://www3.epa.gov/pesticides/chem_search/reg_actions/reregistration/fs_ G-67_1-Dec-93.

EPA, 2004. Registration Eligibility Decision (RED) PAKTM 27 (sodium carbonate peroxyhydrate with active ingredient hydrogen peroxide), Human and Ecological Risk Assessment for Section 3 Registration of the end-use product PAKTM 27 for application to lakes, ponds, and drinking water reservoirs, DP\#301201, PC\#000595, EPA File Symbol No. 68660-O; US EPA, Office of Pesticide Program, November 9, 2004.14 Massachusetts Department of Environmental Protection Massachusetts Department of Agricultural Resources

EPA. 2012. Alternative Disinfection Methods Fact Sheet: Peracetic Acid. US Environmental protection Agency, Office of Wastewater Management EPA 832-F-12-030 D.C.

Feliziani, E.; Lichterb, A. J.; Smilanickc, L. and Ippolito, A. 2016. Disinfecting agents for controlling fruit and vegetable diseases after harvest. Postharvest Biology and Technology, 122:53-69.

Galal, A. A. 2003. Pantoea ananas (Erwinia herbicola subsp. ananas), a new pathogen to tomato plants. The $10^{\text {th }}$ Cong. of the Egypt. Phytopathol. Soc., 9-10 Dec., Giza, Egypt. pp. 325-338. 
Gómez-López, V.M., 2012. Decontamination of Fresh and Minimally Processed Fresh Produce, $1^{\text {st }}$ Ed., John Wiley and Sons, Inc.

Himel, R. M.; Khan, A. A. and Reza, M. E. 2017. Effect of some chemicals against bacterial soft rot of fruits. Journal of Bioscience and Agriculture Research, 13(1):1087-1091.

Hopkins, D. L.; Hilgren, J.; Lovic, B. and Thompson, C. M. 2003. Wet seed treatment with peroxyacetic acid for the control of bacterial fruit blotch and other seed borne diseases of watermelon. Plant Disease, 87(12):1495-1499.

Hopkins, D. L.; Thompson, C.M. and Lovic, B. 2009. Management of transplant house spread of Acidovorax avenae subsp. citrullion cucurbits with bactericidal chemicals in irrigation water. Plant Health Progress, Website: http://www.plantmanagementnetwork.org/pub/php/research/2009/acidovorax/.

Imlay, J.A. and Linn, S., 1988. DNA damage and oxygen radical toxicity. Science, 240:1302-1309.

Kachroo, A.; He, Z.; Patkar, R.; Zhu, Q.; Zhong, J.; Li, D. ; Ronald, P.; Lamb, C. and Chattoo, B. B. 2003. Induction of $\mathrm{H}_{2} \mathrm{O}_{2}$ in transgenic rice leads to cell death and enhanced resistance to both bacterial and fungal pathogens. Transgenic Research, 12: 577-586.

Kang, H. C.; Park, Y.H. and Go, S.J. 2003. Growth inhibition of a phytopathogenic fungus, Colletotrichum species by acetic acid. Microbial Res., 158(4):321326.

Kiraly, Z.; El-Zahaby, H.; Galal, A. A.; Abdou, S.; Adam, A.; Barna, B. and Klement, Z. 1993. Effect of oxy free radicals on plant pathogenic bacteria and fungi and on some plant diseases. In G.Y. Mozsik; I. Emerit; J. Feher; B. Mathovics and A. Vincze (eds.). Oxygen Free Radicals and Scavengers in the Natural Sciences. AkademiaiKiado, Budapest, pp. 9-19.

Kitis, M. 2004. Disinfection of wastewater with peracetic acid: A review, 30(1):47-55.

Narcis, J.A.; Baldwin E.A; Plotto, A. and Ference, C.M. 2007. Preharvest peroxyacetic acid sprays slow decay and extend shelf life of strawberries. HortScience, 42(3):617-621.

Neler, J.; Wassermann, W. and Kutner, M.H. 1985. Applied linear statistical models. In: Richard, D.(ed.) Regression Analysis of Variance and Experimental Design : $2^{\text {nd }}$ Irwin Inc. Homewood Illionois. pp: 117-155.

Opara E.U. and Austin, A.A. 2016. An Overview of characterization and identification of soft rot bacterium Erwinia in Some vegetable crops. Review article (DOI:http://doi.org/10.15580/GJBS.2016.3.041 916078).

Osório. T.G.; Oliveira, B. S. and Di Piero, R.M. 2013. Effect of fumigants on blue and grey moulds of apple fruit. Tropical Plant Pathology, 38(1):63-67. 
Ouf, M.F.; Gazar, A.A.; El-Sadek, S.A.M. and Galal, A.A. 1991. Effect of some plant extracts on growth and enzyme activities of soft rot bacteria. Egypt. J. Microbiol., 26:157-169.

Pfuntner, A. 2011. "Sanitizers and Disinfectants: The Chemicals of Prevention." Food Safety Magazine. https://www.foodsafetymagazine.com/magazine.

Quan, L.I.J.; Zhang, B. O.; Shi, W. and Li, Y.H. 2008. Hydrogen peroxide in plants: a versatile molecule of the reactive oxygen Species Network. Journal of Integrative Plant Biology, 50(1):2-18.

Sargent, S.A.; Ritenour, M.A. and Brecht, J.K., 2000. Handling, Cooling and Sanitation Techniques for Maintaining Postharvest Quality. University of Florida Cooperative Extension Service, Institute of Food and Agriculture Sciences, EDIS. 1-17.

Shetty, N.P.; Mehrabi, R.; Lütken, H.; Haldrup, A.; Kema, G.H.J.; Collinge, D.B. and Jørgensen, H.J.L. 2007. Role of hydrogen peroxide during the interaction between the hemibiotrophic fungal pathogen Septoria tritici and wheat|. New Phytologist, 174(3): 637-647.

Ślesak, I.; Libik, M.; Karpinska, B. and Stanislaw. 2007. The role of hydrogen peroxide in regulation of plant metabolism and cellular signalling in response to environmental stresses. Acta Biochemical Polonica., 54(1): 39-50.

Tatsuzawa, H.; Maruyama, T.; Misawa, N.; Fujimori, K.; Hori, K.; Sano, Y.; Kambayashi, Y. and Nakano, M., 1998. Inactivation of bacterial respiratory chain enzymes by singlet oxygen. FEBS Letters, 439, 329-333.

Thipaksorn, C.; Rattanapanone, N. and Boonyakiat, D. 2012. Effects of peroxyacetic acid, peroxycitric acid, sodium bicarbonate, potassium sorbate, and potassium metabisulfite on the control of green mold in Sai Nam Phueng tangerine fruit. CMU. J. Nat. Sci., 11(2): 203-211.

Wessels, S. and Ingmer, H. 2013. Modes of action of three disinfectant active substances: A review. Regulatory toxicology and Pharmacology, 67(3):456-467.

Yanong, R.P.E. and Reid, C.E. 2012. Biosecurity in Aquaculture, Part 1: An Overview. Southern Regional Aquaculture Centre. No. 4707.

Youssef, N.S.; Awad, E.M.M. and Galal A.A. 2006. Effect of calcium sources on yield, quality and development of dry and soft rot diseases on some potato varieties. Mansoura University J. of Agric. Sci., 31:(6) 3801-3814.

(Received 10/8/2017;

in revised form 20/9/2017) 


\section{تقييم بيروكسي حمض الخليك (PAA) في مكافحة العفن الطري البكتيري لبعض ثمار الخضر ودرنات Erwinia البطاطس المتسبب البكتيري عن البكتيريار carotovora subsp. carotovora} قأنور عبد العزيز جلال ملية الزراعة ـ ـامعة المنيا

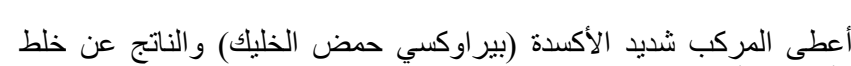

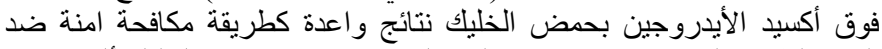

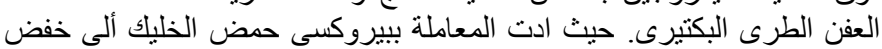

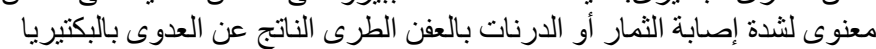
Erwinia carotovora subsp. carotovora

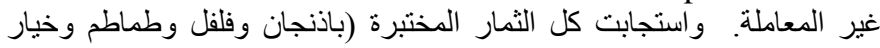

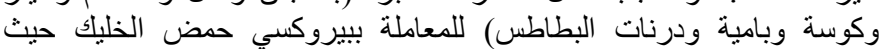

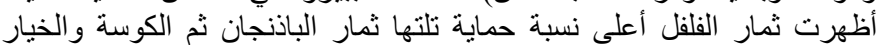

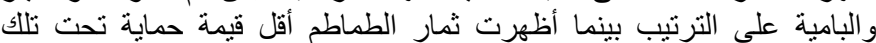

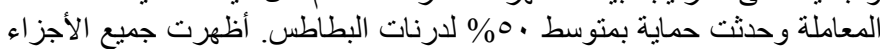

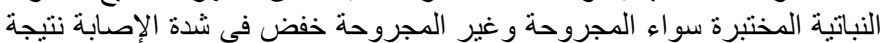

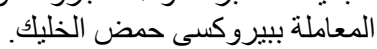

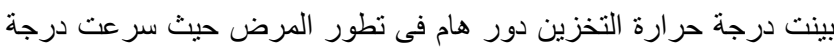

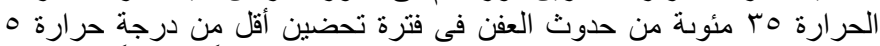

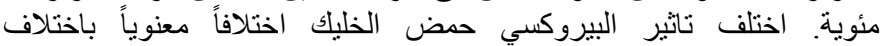

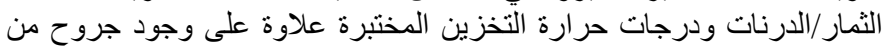

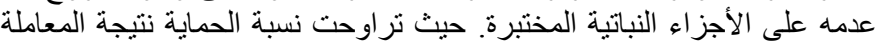

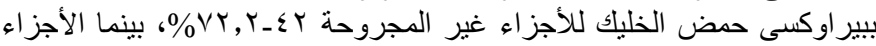

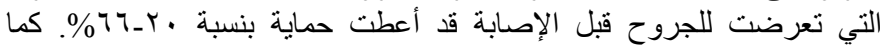

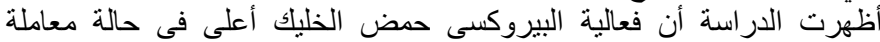

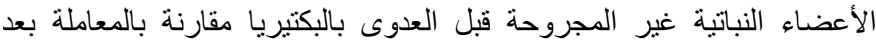

